\title{
11
}

\section{Sentencing Acts: Appraisal of Court Records in Canada and Australia}

\author{
Trish Luker
}

\section{Introduction}

In archival theory and practice, sentencing is the process of identifying and classifying information, potentially resulting in its destruction. It is a surprising homonym to judicial pronouncement of criminal punishment, despite the emotive association with censorship and book burning. In archival science, as in law, sentencing is the result of evaluative judgment. In the case of archival science, these judgments about historical and social value, institutional accountability and resourcing have a powerful impact on social memory because they determine which 'creators, functions, and activities in society will be represented in archives'. ${ }^{1}$

In the practice of archival appraisal, records are sentenced in accordance with a disposal authority-a documented appraisal framework for decisions about preservation or disposal of records. However, disposal does not necessarily mean that the records are destroyed; it may mean that they are transferred to another institution or even to a national archive to

1 Terry Cook, 'Documenting Society and Institutions: The Influence of Helen Willa Samuels' in Terry Cook (ed), Controlling the Past: Documenting Society and Institutions_Essays in Honor of Helen Willa Samuels (Society of American Archivists, 2011) 2. 
be retained. Particularly from the mid- $20^{\text {th }}$ century, the proliferation of documentation resulting from bureaucratisation and rapid technological developments has meant that 'choices had to be made about what to maintain'. ${ }^{2}$ It is now generally acknowledged that not all records can, or should, be preserved and that resources should not be wasted on keeping records longer than necessary.

In Australia, federal government agencies cannot dispose of records without authorisation from the National Archives of Australia (NAA). ${ }^{3}$ This is also the case in Canada, where permission for destruction of Canadian government records must be obtained from Library and Archives Canada (LAC). ${ }^{4}$ However, in both jurisdictions, courts are subject to archives legislation only to a limited extent, ${ }^{5}$ resulting in uncertainty about responsibilities and rights in relation to court records. In the absence of obligations under archives legislation, courts have drawn on a range of frameworks to make decisions about preservation and disposal, including legal principles and obligations, information management requirements, administrative needs and constraints, and jurisdictional obligations. However, attempting to reconcile these (sometimes competing) obligations has resulted in incoherent and inconsistent decisions about preservation and disposal of records. In some instances, it has also resulted in contentious public debates, legal conflict and litigation.

This chapter considers the role of courts as archives through an examination of approaches to appraisal and disposal of court records. Drawing on fieldwork conducted in Canada and Australia, I will demonstrate how superior courts of record in these jurisdictions have attempted to address their legal and institutional responsibilities, to varying points of resolution. I begin by identifying a number of disputes over the preservation and destruction of records from legal inquiries and court processes, drawing

2 Sue McKemmish, Barbara Reed and Michael Piggott, 'The Archives' in Sue McKemmish, Michael Piggott, Barbara Reed and Frank Upward (eds), Archives: Recordkeeping in Society (Centre for Information Studies, Charles Sturt University, 2005) 175.

3 Archives Act 1983 (Cth) ('Archives Act'). Section 6(1) of the Act gives the NAA power to authorise the disposal or destruction of Commonwealth records; $s 24$ gives agencies responsibility for destruction, transfer or alteration of Commonwealth records, subject to the authorisation of the NAA.

4 Library and Archives Canada Act, SC 2004, c 11, s 12(1) ('Library and Archives of Canada Act').

5 In Australia, the Archives Act s 19(1) specifies that the legislative provisions concerning Commonwealth records, including disposal and destruction, do not apply to records in the possession of a court or court registry, unless Regulations so provide. In Canada, the Library and Archives of Canada Act applies only to government institutions, as defined in the Access to Information Act, RSC 1985, c A-1, Schedule 1. No courts are covered by this legislation. 
on examples from the Australian and Canadian contexts. These disputes highlight the importance of some of the questions posed by the Court as Archive Project; questions that courts in both jurisdictions have been attempting to grapple with over recent years. What responsibilities do courts have, as institutions of legal authority and record, to preserve, curate, store and provide access to records of their adjudication? What principles should guide and determine appraisal decisions about what to keep and what to dispose of? How should courts balance the (sometimes competing) obligations to the principle of open justice and litigants' right to privacy and confidentiality? Are some court records so significant as to be preserved in perpetuity and, if so, what principles should guide the selection of these records?

I have chosen to highlight disputes over the destruction of records concerning Indigenous and First Nations, Inuit and Métis peoples. These records, and disputes about them, bring into stark relief some of the competing public, institutional, political and ethical demands faced by courts and other legal bodies concerning their responsibilities as archives. Rather than seeing these disputes as exceptions to general principles and challenges, in the Court as Archive Project, we regard them as paradigmatic examples that can assist courts to develop appropriate institutional archival policies and practices. As Australian archivist Michael Piggott argues, more attention to archival histories, such as histories of acquisition and destruction of records, could help explain current community views of the past and benefit current social debate, especially in relation to Indigenous records. ${ }^{6}$

In Australia, from the early 1990s, the development of native title jurisprudence, as well as other areas for Indigenous claims, including litigation concerning the legality of genocide, cultural heritage claims and compensation by members of the Stolen Generations, resulted in the production of an extensive body of evidentiary and litigation materials for the purposes of legal action. Under the Native Title Act 1993 (Cth), for example, claimants must provide evidence that they possess communal, group or individual rights and interests in relation to land or waters under traditional laws and customs. This is an onerous burden of proof, requiring that claimants demonstrate an ongoing connection to the land in question, dating back to the assertion of colonial sovereignty. In addition to witness

6 Michael Piggott, Archives and Societal Provenance: Australian Essays (Chandos Publishing, 2012) 238, doi.org/10.1533/9781780633787. 
statements, it may include genealogies, anthropological, historical and linguistic reports, maps, photographs, artworks and other material. The Federal Court has been conscious of the historical value of the records produced for the purposes of litigation and its responsibilities for them as a court of record with obligations to the national interest. However, for many years, it did not have a suitable archival appraisal framework on which to base decisions about what to preserve and what to destroy. This points to the significant interrelationship between the development of the Federal Court's approach to its record-keeping obligations alongside developments in its native title jurisdiction. ${ }^{7}$

Where Australian and Canadian courts of record have attempted to resolve questions about record-keeping responsibilities, they have drawn primarily upon legal principles and obligations, including the need to preserve records of judicial decisions for the purposes of precedent; the civil law principle of 'open justice'; the rights of individual litigants to privacy; the maintenance of legal professional privilege; and the need to protect certain groups, such as children. Further, as for all public institutions, decisions by courts about record-keeping have been driven by rapid changes and developments in technology, as well as increasing constraints on financial resources and storage space. As a result of these imperatives, and despite the lack of legislative coverage, superior courts of record in both Canada and Australia have engaged in negotiations with national archives institutions, the NAA and LAC, seeking arrangements for custodianship of case file records, once the case is closed.

Legal principles and obligations are necessary and important requirements for courts' approaches to decisions about appraisal and disposal of records. However, federal supreme courts of record should also consider their archival responsibilities in terms of the deeper public law issues underlying their institutional role. Courts can benefit from approaches reflected in contemporary archival theory, where it is recognised that appraisal choices are political and ethical because they 'shape the future of our jurisdiction's documentary heritage'. ${ }^{8}$ Drawing on such a framework will assist courts in developing their archival responsibilities beyond consideration of the need to preserve legal records of individual disputes, but rather as records that are of public interest and importance because they reflect societal

7 See Chapter 7, this volume.

8 Terry Cook, 'Macroappraisal in Theory and Practice: Origins, Characteristics, and Implementation in Canada, 1950-2000' (2005) 5 Archival Science 101, 103. 
dynamics and public issues. As Canadian archivist Terry Cook explains, 'archivists should focus on the mechanisms or loci in society where the citizen interacts with the state to produce the clearest evidence of societal dynamics and public issues, and thus of societal values'. 'This is a valuable framework for informing the development of archival principles for federal superior courts of record because of their important role in adjudicating claims and disputes of a democratic society, and as a legal archive of national value.

The aim of the Court as Archive Project has been to clarify the institutional purposes and civic responsibilities of Australian supreme courts of record through their archival role. In particular, we have focused on the unique role of the Federal Court of Australia as a site for production of significant national archives. We have also ventured to develop principles to inform the administration of the court's records, as a responsive civic institution in $21^{\text {st }}$-century Australia. The chapter concludes with an account of the development of the Federal Court's records authority that sets out the current framework for the management and disposal of its case file records. I focus, in particular, on the rationale for the definition of what constitutes a 'court record' and the identification of a 'significant' case. This history importantly reveals the extent to which the negotiations between the Federal Court and the NAA have provided the defining context for the meaning of the 'court record' in Australian superior courts of record. It demonstrates the importance that histories of archives theory and practice play in defining legal and court practices. ${ }^{10}$

\section{Gaps in the Records}

Appraisal has been described as the 'critical archival act', the archivist's 'first responsibility', ${ }^{11}$ but also as 'the most vexed issue in archival practice in the early twenty-first century'. ${ }^{12}$ Perhaps, as Sue McKemmish, Barbara Reed and Michael Piggott suggest, because appraisal has not always been part of archival practice, 'pragmatic and practice-based approaches became the core guides. ${ }^{13}$ However, it is now well-recognised among archival thinkers

9 Ibid 125-6.

10 The interview with Warwick Soden, CEO, Federal Court of Australia, in Chapter 7 of this volume, provides an account of this history from the Federal Court's perspective.

11 Cook, above n 1, 2.

12 McKemmish, Reed and Piggott, above n 2, 175.

13 Ibid. 
that appraisal, like other areas of archival work, involves decisions about far more than the availability of storage space and financial resources. Archival appraisal results in the creation of archives as institutions and, for this reason, decisions about what to keep and what to destroy requires sensitivity to the 'political, social, philosophical and ethical nature of appraisal'. Indeed, Terry Cook goes so far as to suggest that, as a society, 'we are what we do not keep, what we consciously exclude, marginalize, ignore, destroy. ${ }^{14}$

The truth of this aphorism is clearly demonstrated in settler colonial polities, such as Australia and Canada, when contentions over the reliability and interpretation of state-produced archival records have come into sharp relief, notably as a result of legal avenues and processes of reconciliation with Indigenous peoples. For example, in Australia, research conducted during the 1990s for the National Inquiry into the Removal of Aboriginal and Torres Strait Islander Children from their Families revealed destruction, under authorised procedures, of a range of records, including adoption and fostering case files across state jurisdictions. ${ }^{15}$ The inquiry received a number of submissions concerning the difficulties Indigenous people experience in gaining access to archival records held by the various record-keeping agencies. ${ }^{16}$ Some stated that 'government agencies had destroyed or lost particular classes of records relating to adoption, foster care or personal information, either through deliberate culling or through fires in the buildings that housed the records ${ }^{17}$ There was also an unexplained gap in Aborigines Welfare Board files for an entire decade: $1938-48 .{ }^{18}$ Further, as the inquiry pointed out, records made and held by non-government organisations, including churches that ran children's homes and orphanages, are neither required to retain records nor to provide access to these records under Freedom of Information legislation. ${ }^{19}$ As a result of these revelations, the inquiry made a number of recommendations in relation to changes to archival records management

14 Terry Cook, "We Are What We Keep; We Keep What We Are": Archival Appraisal Past, Present and Future' (2011) 32(2) Journal of the Society of Archivists 173, 174.

15 Human Rights and Equal Opportunity Commission, Bringing Them Home: Report of the National Inquiry into the Separation of Aboriginal and Torres Strait Islander Children from Their Families (1997), 325-6.

16 Ibid 348.

17 Sonia Smallacombe, 'Accessing Personal and Family Records: Contesting the Gatekeepers' [1998] Indigenous Law Bulletin 2.

18 Above n 15, 325-6.

19 Above n 15, 333-4. 
practice, including a moratorium on destruction of records relating to Indigenous individuals, families or communities held by government or non-government agencies. ${ }^{20}$

This was not the only time recommendations have been made in relation to record-keeping after legal inquiries. Kim Eberhard points out that in at least eight key inquiries into various aspects of the welfare of children conducted in Australia since 1989, recommendations were made in relation to record-keeping, even when the terms of reference did not mention these matters. She argues that commissioners conducting these inquiries have been 'confronted with the centrality of records to their inquiries, and that a lack of records has been the most critical factor leading to recommendations concerning record-keeping in both public and private sectors'. ${ }^{21}$

In Canada, there have also been controversies surrounding the destruction of government and legal records. During the late 1980s, a furore emerged in the context of the Royal Commission of Inquiry to investigate the charge that Canada was a haven for Nazi war criminals. ${ }^{22}$ The National Archives of Canada was called to give evidence about its records management policy and processes, and many government officials were surprised to learn that not all immigration and security case records were retained in perpetuity. ${ }^{23}$ Terry Cook, one of the archivists from the Canadian National Archives involved in the appraisal decisions resulting in the destruction of the records, has written extensively about the impact, personally and professionally, of the revelations that valuable historical records concerning human rights violations had been destroyed. He argues that this marked the beginning of a new approach to appraisal and disposal at NAC with national and international impact. ${ }^{24}$

20 Above n 15, Recommendation 21: Destruction of Records Prohibited, 347.

21 Kim Eberhard, 'Unresolved Issues: Recordkeeping Recommendations arising from Australian Commissions of Inquiry into the Welfare of Children in Out-of-Home Care' (2015) 43(1) Archives and Manuscripts 4, 6.

22 Commission of Inquiry on War Criminals in Canada, Report and Findings (Privy Council Office, Canada, 1986).

23 Terry Cook, "'A Monumental Blunder”: The Destruction of Records on Nazi War Criminals in Canada' in Richard J Cox and David A Wallace (eds), Archives and the Public Good: Accountability and Records in Modern Society (Quorum Books, 2002).

24 Ibid 62. 
More recently in Canada, disputes have arisen about responsibility for contemporaneous records of testimonial and documentary evidence produced in proceedings under the Indian Residential Schools Settlement Agreement. ${ }^{25}$ This agreement provided for two avenues of reparations, one of which was for previous students who wished to pursue compensation claims for serious assault and sexual assault. The Chief Adjudicator of the Independent Assessment Process (IAP), Dan Shapiro, sought an order for destruction of the documents at the end of the process to protect the privacy of the survivors and perpetrators. ${ }^{26}$ However, the Truth and Reconciliation Commission sought an order that the documents be archived at LAC on the basis that the narratives produced for the hearings are an irreplaceable historical record of the Indian Residential School experience. ${ }^{27}$ The court granted the Chief Adjudicator's request that the IAP documents be destroyed after a 15 -year holding period by the Canadian Government. However, it also made an order that with the consent of the claimant, and subject to redaction of identifying personal information about alleged perpetrators or affected parties, the records may be archived at the National Centre for Truth and Reconciliation. ${ }^{28}$ On appeal, the Ontario Court of Appeal upheld this decision and a further appeal to the Supreme Court of Canada (SCC) was dismissed. ${ }^{29}$ In a unanimous Full Court decision, the court rejected the argument that the documents were subject to federal access, privacy and archives legislation. ${ }^{30}$

These disputes clearly demonstrate, sometimes in poignant ways, the competing legal, ethical and political demands and expectations associated with decisions about preservation and destruction of legal records. The obligations of courts and other legal entities to maintain records of proceedings may come into direct conflict with the right of individual

25 The Indian Residential Schools Settlement Agreement was agreed to on 8 May 2006. It is a multiple court-approved settlement resulting from approximately 150 individual and class actions taken by former students of Indian residential schools: <www.residentialschoolsettlement.ca/IRS\%20 Settlement\%20Agreement-\%20ENGLISH.pdf>.

26 Fontaine $v$ Canada (Attorney General) 2014 ONSC 4585. The application by the Chief Investigator was supported by the Assembly of First Nations, the Twenty-Four Catholic Entities, the Nine Catholic Entities, the Sisters of St Joseph and Independent Counsel.

27 The application by the Truth and Reconciliation Commission was supported by the Canadian Government and the National Centre for Truth and Reconciliation.

28 The National Centre for Truth and Reconciliation, based at the University of Manitoba, was established 'to preserve the memory of Canada's Residential School system and legacy' as the permanent home for all statements, documents and other materials gathered by the Truth and Reconciliation Commission of Canada: <http://nctr.ca/map.php/>.

29 Fontaine $v$ Canada (Attorney General) 2016 ONCA 241.

30 Canada (Attorney General) v Fontaine [2017] 2 SCR 205. 
litigants to privacy or the need to respect Indigenous control of cultural knowledge. At the same time, the record of the court's proceedings produced by the court is of significant national archival value, as it records the claims and disputes of a democratic society. They are rich records of public interest and importance about the relationship between the individual and the state that are not readily accessible elsewhere.

Further, these disputes highlight the unique characteristics of records produced by courts in the course of litigation, which may include transcripts of oral testimony, expert witness reports, evidentiary materials, photographs, affidavits and other court records. As Cornelia Vismann argues, files are the foundation of legal activity, but they 'remain below the perception threshold of the law'. ${ }^{31}$ Records presented in litigation may have been sourced from established state- or privately owned archives, or they may have been created specifically for the litigation on the basis of new research or investigations. These records may subsequently be incorporated into or associated with new records, being records of disputes between parties. As records of court processes, they are generally subject to the legal principle of open justice. However, this is not always the case, as some proceedings are held in closed courts or are subject to confidentiality requirements. The specific characteristics of court and legal records suggest the need for an approach to archival appraisal that recognises their value not only as records of proceedings of claims and disputes, but also as archives documenting changes in understandings of political demands, and democratic expressions about rights and values.

\section{Archival Appraisal}

In Australia and Canada, archives legislation provides the legal framework for preservation and disposal of government records through the establishment of national archives institutions. ${ }^{32}$ In both jurisdictions, the legislation was introduced as part of the administrative law packages

31 Cornelia Vismann, Files: Law and Media Technology (Stanford University Press, 2008) 11.

32 In Australia, the Archives Act 1983 (Cth) ('Archives Act'), established the NAA to 'ensure the conservation and preservation of the existing and future archival resources of the Commonwealth' (s 5(2)(a)). In Canada, the National Archives of Canada Act, RSC 1985 (3' $3^{\text {rd }}$ supp), c 1 ('National Archives of Canada Act') established the National Archives of Canada 'to conserve private and public records of national significance' and 'to be the permanent repository of records of government institutions and of ministerial records' (s 4(1)). The National Archives of Canada Act was repealed by the Library and Archives of Canada Act, which established the LAC. 
in the 1970s, including Freedom of Information legislation that was intended to provide improved access to government information. However, based on the principle of the separation of powers between the executive and the judiciary, the records of courts are specifically exempt from the operation of archives legislation. ${ }^{33}$ Nevertheless, faced with exponentially increasing case loads and decreasing availability of archival storage space, superior courts of record in each jurisdiction have engaged in negotiations with national archives for transfer and custodianship of court archives, including case file records..$^{34}$

Under the Australian Archives Act, the NAA has power to authorise the disposal or destruction of Commonwealth records,${ }^{35}$ giving government departments and agencies responsibility for destruction, transfer or alteration of Commonwealth records, subject to its authorisation. ${ }^{36}$ The Archives Regulations 1984 (Cth) provide the framework for appraisal and disposal of records, including the requirements for consent to destruction from both the NAA and the Commonwealth institution. ${ }^{37}$ In Canada, archival appraisal is conducted by the national archives institution, LAC, in consultation with federal government agencies. The consent of the National Archivist must be obtained for destruction and disposal of records. ${ }^{38}$

In an article that considered disposal practices under the Australian Archives Act from an administrative law perspective written some 20 years ago, Kim Rubenstein argued that the legal framework for records destruction is sparse. While the NAA has the responsibility for determining the practices and procedure appropriate for disposal, the Act does not provide clear direction because it does not contain an objects clause that sets out

33 Archives Act s 19. In Canada, the Library and Archives of Canada Act does not cover federal courts. In Australian states and territories, New South Wales alone specifically excludes court and tribunal records from obligations under the State Records Act 1998 (NSW) ss 9(1)(c) and (2), 26(1)(c), $49(1)(c)$ and (2). In most Canadian provinces, records legislation includes provisions for archiving of court records. For example, the Saskatchewan Archives and Public Records Act, SS 2015, c A-26.11 provides for management of Court of Appeal records, including administrative records. However, in some jurisdictions, provisions specify a long period for court retention prior to transfer.

34 See Chapter 4, this volume.

35 Archives Act s 6(1).

36 Archives Acts 24.

37 Archives Regulations 1984 (Cth) regs 3-7.

38 National Archives of Canada Act s 3; Library and Archives Canada Act s 12(1). 
fundamental principles to guide the decision-makers in what is worthy of disposal. She suggested that there was not enough guidance in the Act and that there was a lack of accountability. ${ }^{39}$

Since this time, responsibility for government record-keeping practices in Australia has devolved even further to the agency level, through the extensive use of records retention and disposal authorities (RDAs). ${ }^{40}$ The NAA has tasked itself with responsibility for the selection and preservation for retention of the most important information identified as being of permanent (or continuing) value due to its national significance or public interest. All other records are the responsibility of the agency that created or controls the information, although decisions about what to retain, and for how long, are made through the development and implementation of RDAs. These allow government authorities to make decisions about preservation, destruction or transferral of records at the department or agency level, in accordance with frameworks established by the agency in consultation with the NAA. Some RDAs are general and apply to areas such as administrative functions across agencies, others are agency-specific. The framework outlined by the NAA for records management stresses the need to reduce business risk, increase accountability and improve operational efficiencies. It identifies the context of limited financial resources and storage space as rationales for records destruction. ${ }^{41}$

Despite lack of legislative requirement, RDAs have been established by courts and tribunals with federal jurisdiction, including the Federal Court of Australia, to cover specific areas of operation. For example, disposal of the administrative files is authorised by a general Administrative Functions Disposal Authority, applying to all federal government activity and covering an extensive range of records of administrative practices. ${ }^{42}$ Under the authority, government departments and agencies are permitted to dispose of certain 'low-value and short-term information' considered

39 Kim Rubenstein, 'Erring on the Side of Destruction? Administrative Law Principles and Disposal Practices under the Archives Act 1983 (Cth)' (1997) 4 Australian Journal of Administrative Law 78, 82.

40 Archives Act s 24.

41 National Archives of Australia, Records Authorities (2018) <www.naa.gov.au/information-manage ment/records-authorities>.

42 National Archives of Australia, Administrative Functions Disposal Authority (AFDA), (Revised March 2010) (2018) <www.naa.gov.au/Images/AFDA2010-7Feb2013-revision_tcm16-44429.PDF>. 
part of normal administrative practice, including draft notes, temporary materials and such. ${ }^{43}$ It is only once an RDA is established that sentencing can occur, performed by the agency itself, but authorised by the NAA.

Notwithstanding the proliferation of RDAs, archival appraisal is ultimately an interpretative act. The decision as to whether a record is appraised as worthy of retention and preservation is a process that results in only some records being attributed status as archives. As Canadian archivist Tom Nesmith argues:

The destruction or exclusion of non-archival records 're-creates' the surviving records by repositioning them in the archives vis-à-vis related records, or by removing aspects of their context of interpretation. The records elevated to the status of archives then become the focus of the meaning-making or interpretive process, which in turn makes and remakes them. ${ }^{44}$

In this way, archival practices of appraisal shape records and selectively establish relationships among records that did not necessarily exist before archivists created them and, thus, foster some interpretive possibilities and diminishing others.

Similarly, the framework drawn upon to establish principles and approaches to appraisal and sentencing have been subject to change and have themselves been influenced by theoretical developments in archival theory, history and other disciplines. For most of the $20^{\text {th }}$ century, archival appraisal based its decision-making on what to keep and what to destroy 'primarily on assessing actual or anticipated research uses of records, particularly for writing academic history. ${ }^{45}$ However, 'value through use' is now recognised as an inadequate basis for archival appraisal. Fundamental changes in understandings of history and historiography that developed during the late $20^{\text {th }}$ century have contested the historical authority attributed to archivally based history, identifying the way it reflects the history of hegemonic, rather than the marginalised, oppressed and subaltern. ${ }^{46}$ There has also been a significant expansion of conceptual

43 National Archives of Australia, Normal Administrative Practice (2018) <www.naa.gov.au/ information-management/managing-information-and-records/disposal/NAP/index.aspx>.

44 Tom Nesmith, 'Seeing Archives: Postmodernism and the Changing Intellectual Place of Archives' (2002) 65 The American Archivist 24, 34.

45 Cook, above n 23, 59.

46 Francis X Blouin Jr and William G Rosenberg, Processing the Past: Contesting Authority in History and the Archives (Oxford University Press, 2012). 
understandings of 'the archive' and increased use of archival sources by disciplines outside academic history, including law. ${ }^{47}$ In settler colonial contexts such as Canada and Australia, this has notably included the use of archival sources as historical evidence in legal actions in relation to land rights, treaty rights, cultural heritage and compensation for loss in relation to stolen children and wages. Importantly, the court case file records of these actions themselves provide valuable accounts of the claims and disputes that reflect the changing nature of society.

\section{Appraisal at Courts of Record}

Developments in archival theory recognise the outdated notion that archivists simply and invisibly process records for future use. As Tom Nesmith points out, within postmodern understandings of communication, archivists are co-creators and shapers of knowledge in records, and 'thus help form society's memory' ${ }^{48}$ Records are not inert but are continually evolving. He argues that archives-making is a type of authoring or creating:

Some of what makes a record meaningful is inscribed in it by those who literally made it, but most of what makes a record intelligible lies outside its physical borders in its context of interpretation. Archivists, who do much to shape this context, therefore share in authoring the record. ${ }^{49}$

The increased sophistication of theoretical approaches to archival appraisal has had a significant impact on records retention policies internationally. New conceptual and methodological approaches to archival appraisal, such as 'macroappraisal', attempt to reflect 'a broader spectrum of human experience in society and to mirror more closely therefore society's own values, rather than more narrowly the values of powerful records creators or those derived from anticipating use patterns.${ }^{50}$ Macroappraisal has been adopted in Canada as the official appraisal strategy at LAC and has been very influential at the NAA, employed as a 'functions-based' approach, in conjunction with individual agencies. It is a top-down approach that

47 See contributions to 'Evidence and the Archive: Ethics, Aesthetics, and Emotion' (2014) 40(1) Australian Feminist Law Journal 1.

48 Nesmith, above n 44, 31.

49 Ibid 32.

50 Cook, above n 23, 62 . 
requires assessment of the value of records not at the level of the individual document or file, but, rather, at the level of the organisation, department or government.

While superior courts of record in Australia and Canada have been included in the ambit of application of RDAs for general records, they have encountered obstacles and delays in developing and obtaining agreements for authorities in relation to case file records. The overriding principle of the separation of powers, the absence of imprimatur under archives legislation, competing demands for financial and space resources, as well as the unique characteristics of court records are all factors that have contributed to these challenges. In particular, when engaged in the process of developing frameworks for archival appraisal through records RDAs, superior courts of record in Canada and Australia have been confronted with a question that goes to the heart of their identity and ultimately defines their record-keeping responsibilities—namely 'What is a court record?'. In the following section, I will explain how superior courts of record in Canada and Australia have engaged with archival appraisal, with particular attention to the question of what constitutes a court record.

\section{What is a Court Record?}

During 2015, I conducted fieldwork for the Court as Archive Project in Canada, with attention to developments in records management at the key federal courts of record, the Supreme Court of Canada and the Federal Court of Canada, as well as the federal archival institution, LAC.

\section{Supreme Court of Canada ${ }^{51}$}

The SCC is the highest court in Canada's federal court system, adjudicating approximately 80 cases per year; it deals only with appeals, and no evidentiary material is presented. As the court with final judicial authority in the nation, its decisions establish legal precedent. For this

51 The information contained in this section is based on communication with David Rajotte and Michael MacDonald, archivists from Library and Archives Canada on 9 September 2015; Etienne Perras, Manager, Library and Information Management Branch, Supreme Court of Canada on 9 September 2015; and Barbara Kincaid, General Counsel and Director-General, Court Operations Sector, Supreme Court of Canada on 3 November 2015, and her subsequent participation, via Skype, in the Court as Archive Symposium, The Australian National University, 17 February 2016. 
reason, since its establishment in 1875 , the court's policy in relation to record-keeping of case files has been to 'keep everything'. ${ }^{52}$ Until 2009, case file documents were maintained in paper form and stored in the court's records centre. Starting in the 1980s, the court began producing microfilm of case files, progressively establishing a comprehensive record dating back to 1875 . In 2009, the court introduced electronic document management and records management and, since this time, has made available to the public live and archived webcasts of its hearings.

In 1977, the court signed an agreement with LAC to transfer case file records for preservation once the court file was closed. One copy of the microfilm is maintained at the court registry and the original files, together with a second microfilm copy, are transferred to LAC. This transfer arrangement occurs every two to three years, but it does not include cases from the most immediate past years. In 1991, a transfer agreement between the SCC and LAC was signed, which meant that all publicly filed documents contained on the case files from 1875-1945 were transferred to LAC for care and custody, although the court continued to own the material. LAC provides unlimited public access to all Supreme Court files unless the material has been identified by the court as restricted. Public access is available at LAC via the online catalogue and includes the video recordings of hearings. ${ }^{53}$

In 2003, the court began negotiating a comprehensive agreement with LAC for permanent transfer of records deemed to be of enduring value. Barbara Kincaid, General Counsel, SCC, explained that the protracted negotiations to develop the court's retention policy raised for the court important questions about how to define the court record: questions that, as a court of record, it was imperative the court resolve because the answer to this question determines what records the court is required to preserve permanently. For example, in attempting to balance the open court principle with individual rights to privacy and security, is it acceptable for the court to place limits on public access to court records, media and parties to the proceedings where there are statutory publication bans, sealing orders or statutory restrictions on access to case files? In keeping with its vision of making its collection accessible to the Canadian public,

52 Interview with Barbara Kincaid, General Counsel and Director-General, Court Operations Sector, Supreme Court of Canada (Ottawa, 3 November 2015).

53 Email from Barbara Kincaid, General Counsel and Director-General, Court Operations Sector, Supreme Court of Canada, to Trich Luker, 3 November 2015. 
LAC would like to digitise the microfilm collection. However, what happens to sensitive information in older case files? What is the risk given that personal identifiers and other sensitive information may be contained in closed case files? Further, how does the court distinguish between judicial information, such as records of judicial deliberations, and public information-namely, what is on the official court record? ${ }^{54}$

In 2017, a comprehensive agreement between the SCC and LAC was finalised. It provides the terms for the provision of perpetual care and public access to SCC 'information resources of enduring value' (IREV). Under the agreement, 50 years following closure of the case file, the Supreme Court will donate to LAC records identified as case-related operational documents that are IREV. This includes the court records filed by litigants or produced by or on behalf of the court; specifically, applications for leave to appeals, appeals and reference documents identified as case files, docket information, judgments, statistical reports concerning the variety of cases heard before the court, and audio, video or web recordings of hearings. ${ }^{55}$ Under the agreement, the SCC is responsible for identifying records that, as a result of a legal obligation, court order or administrative classification, result in limits on accessibility or dissemination. LAC must consult with SCC before providing access to restricted information.

Different conditions apply to collegial judicial documents, including correspondence, memorandums and notes created by a justice, chambers' personnel, law clerks or legal counsel of the SCC in relation to judicial proceedings before the court. Once operational use has ceased, these will be transferred to LAC. However, they will remain closed for 50 years after the case file for the proceeding is closed (with the SCC maintaining control), after which time they become open to the public. ${ }^{56}$

The agreement took 15 years to be negotiated. It appears to provide a comprehensive arrangement for archival appraisal of the case file and administrative records of the SCC, as well as arrangements for public access to these documents. In navigating the question of what is meant by the 'court record', the SCC has taken a broad ambit by including all

54 Barbara Kincaid, 'Administration of Legal Records: Institutional Experiences' (Speech delivered at the Court as Archive Symposium, The Australian National University, 17 February 2016).

55 Agreement between the Office of the Registrar of the Supreme Court of Canada and Library and Archives of Canada, Appendix B, on file with author.

56 The agreement also provides for the donation of the Supreme Court of Canada's administrative records, including registrar and senior management documents, services to justices, legal services and communications, once operational use has ceased. 
of the court's case file records. This is enhanced further by the inclusion of collegial documents, providing access to a rich source of judicial deliberations that illuminate how and why these decisions were made. However, the court has taken a cautious approach to issues of privacy and confidentiality by imposing a 50 -year embargo on the collegial files. ${ }^{57}$

\section{Federal Court of Canada ${ }^{58}$}

The Federal Court of Canada was established in 1971, with a separate appeal division, the Federal Court of Appeal, established in 2003. It is a superior court of record with civil and criminal jurisdiction to hear and decide legal disputes arising in the federal domain, including claims against the Canadian Government, civil actions in federally regulated areas and challenges to the decisions of federal tribunals. As the national trial court, it has a very large volume of cases, with approximately $3,000-4,000$ proceedings heard in court per year. ${ }^{59}$ The magnitude of the court's caseload means that it faces significant challenges in relation to document management strategies. This is demonstrated by the court's failure, to date, to reach an agreement in relation to archival appraisal. In 2006, a report was produced with recommendations for a records retention schedule; however, this has not been implemented. As Andrew Baumberg, Legal Counsel, put it, the report itself became 'an archived document'. ${ }^{60}$ He suggested that one of the key drivers for the court in relation to the development of records retention policies has been the amount of storage space available. As he explained, until around 2013, the court kept everything:

57 The Supreme Court of Canada is the first jurisdiction in Canada to establish an institutional treatment of collegial documents. The decision to impose a 50-year closure period took into account principles of deliberative secrecy, determining that this time period would ensure that judges were unlikely to still be alive when the records were made available: Email from Barbara Kincaid to Trish Luker, 10 November 2017.

58 The information in this section is based on interviews with Andrew Baumberg, Legal Counsel, Federal Court (Ottawa, 6 November 2015) and Lise Albert, Information Management Specialist, Information and Records Management Division, Courts Administration Service (Ottawa, 3 November 2015).

59 Courts Administration Service, 2016-17 Annual Report (2017) 9.

60 Interview with Andrew Baumberg, Legal Counsel, Federal Court (Ottawa, 6 November 2015). In fact, the court found it necessary to amend the Court Rules to allow for establishment of a retention schedule: Federal Courts Rules, SOR/98-106, 23.1. 
I think it's really been something that's ingrained in the judicial culture ... you don't throw things out ... We're in a paper culture which I think has actually really started to shift in the last five years. ${ }^{61}$

As a trial court of record, the Federal Court of Canada has a legal obligation to maintain the court records to support the common law requirement to follow precedent. However, as Baumberg explains, 'precedent doesn't seem to require you to keep all the records that were relied on in order for the judge to write their reasons', particularly in modern legal practice. Given the court's enormous volume of cases, many of which do not go to a full oral hearing, it is attempting to grapple with concerns about the availability of storage space and costs of retaining court files. In 2015-16, the Federal Court of Canada consulted with the Canadian Bar Association. The Bar acknowledged that court records and files might have historical and longer term litigation value. It provided some guidance as to retention periods, according to different areas of practice.

In December 2017, the Federal Court of Canada endorsed key parameters for a retention schedule based on a policy framework that includes specified retention periods for different types of proceedings, with some court documents to be retained in perpetuity. ${ }^{62}$ The court is considering an open approach to its sentencing decisions, with the possibility for members of the public to make submissions justifying extended retention, as well as a small-scale sampling of files for extended retention. Finally, the Federal Court of Canada anticipates that the transition to electronic records will provide lower cost and more efficient archiving. ${ }^{63}$

\section{Federal Court of Australia}

The Federal Court of Australia was established in 1976 as a superior court of record with trial and appellate divisions. It has extensive jurisdiction to deal with most civil disputes governed by federal law

61 Interview with Andrew Baumberg, Legal Counsel, Federal Court (Ottawa, 6 November 2015). 62 The Federal Court of Canada has endorsed a policy of a seven-year retention period for proceedings that were dismissed at leave stage or abandoned/discontinued (ie, not adjudicated on the merits); a 15-year retention of documents in other proceedings; and all docket, judgments, orders and minutes of hearings to be retained in perpetuity: email from Andrew Baumberg to Trish Luker, 20 February 2018.

63 Ibid. 
(other than family law) and a limited number of criminal matters. ${ }^{64}$ In 2015-16, approximately 5,700 causes of action were filed with the court. As discussed in other chapters in this collection, the Court as Archive Project has focused specifically on the Federal Court's archival practices. The decisions this court makes in relation to record-keeping, including appraisal, preservation, custodianship and access, are themselves of public importance, acting as a key indicator of how federal superior courts of record might meet their constitutional mandate and broader democratic responsibilities. ${ }^{65}$

In 1994, the first formal agreement between the Federal Court and the NAA facilitated the transfer of all court administrative and case matter files for storage to the NAA ${ }^{66}$ As in Canada, in the absence of a legislative requirement, one of the key incentives to establishing an agreement was the depletion of storage space within court buildings, resulting in the need for off-site facilities. However, in 2000, the NAA informed the court that, due to its own depleting storage space, it would no longer be able to accept all material. ${ }^{67}$ At this time, the court was developing its electronic court filing system. These two factors were important drivers for the court to enter into negotiations with the NAA in the development of an RDA. Importantly, the development of the RDA reveals the evolution of the court's own understanding what is meant by 'the court record'.

During the 1990s, the NAA advocated a methodology for records management, referred to as DIRKS (Developing and Implementing a Record Keeping System), based on business functions, activities and transactions. ${ }^{68}$ Over a seven-year period, the Federal Court attempted to implement the DIRKS system, with limited success. Other government agencies were also performing poorly in relation to record-keeping because

64 The court's civil law jurisdiction includes administrative and constitutional law, human rights, employment and industrial relations, native title, intellectual property, taxation, trade practices, corporations, appeals from immigration decisions and bankruptcy.

65 See Chapter 4, this volume.

66 National Archives of Australia, Records Disposal Authority for the Federal Court of Australia, Principal and District Registries, Court Records other than Bankruptcy No 1124, 1994. Prior to 1994, files were transferred from the Federal Court to the NAA under less formal arrangements; see Chapter 4 of this volume for a detailed discussion.

67 Lyn Nasir, 'Presentation on the Records Authority' (Speech given at the $9^{\text {th }}$ Australasian Institute of Judicial Administration Librarians Conference, Sydney, 21 August 2015); see also Chapter 7, this volume.

68 This methodology was developed for the implementation of the international principle of the Australian standard for AS4390-1996-Records Management, a codification of ISO15489 for international best practice for record-keeping. 
the DIRKS system was complex and resource-intensive. In 2008, the NAA changed its approach to appraisal, requiring organisations to take greater responsibility at the agency level for identifying documents that defined its 'unique business'. The Federal Court determined that as a court of record, it was court records, rather than administrative records, that fulfilled this role. Further, as a court of record, it determined that the whole of a file constituted the 'record' that should be retained permanently. ${ }^{69}$

However, the NAA has resisted accepting all the Federal Court's case file documents. This has meant that the court has had to consider which court records it believes should be preserved at the NAA as part of the national heritage. It has led to the identification of the criterion of 'significant cases' as the basis for appraisal. However, giving meaning to this criteria has required the court to consider not only its common law role and obligations as a court of record, but also how it sees its responsibilities as a national institution with obligations to the public record. ${ }^{70}$ Importantly, this has been driven by consideration of some of record-keeping issues raised by the unique characteristics of the court's native title jurisdiction. ${ }^{71}$ As Ian Irving, previous Native Title Registrar at the Federal Court points out, court files for native title matters may include 'a rich repository of historical and contemporary cultural and other information', including 'claimant genealogies, expert anthropology, history and/or linguistic reports, witness statements, photographs and other material'. ${ }^{72}$ In considering its archival responsibilities, the Federal Court has had to consider the historical and research value of these records, as well as questions about access to the records.

69 At one stage, on the basis of legal advice obtained from the Australian Government Solicitor, the Federal Court considered an amendment to the Court's Rules to define 'the record' and the retention period, but this was abandoned.

70 Our research into the Federal Court records indicates that, at different times, the court has considered the possibility of the concept of 'significant' to refer to a discretionary approach based on precedent, historical interest (ie, who were the parties, what were the issues), media interest or 'special circumstances'; alternatively, a representative sample, limited to 10 per cent, to be selected by the judges according to different practice areas, has been proposed. Most recently, the court's new approach to case management, the national court framework, is being considered as a framework for identification of significant cases.

71 For further discussion of these issues, see also Chapters 8 and 9, this volume.

72 Ian Irving, 'Information Held on Federal Court Native Title Files' (Speech delivered at the Native Title Conference 2006, Darwin, 1 June 2006) <http://aiatsis.gov.au/publications/presentations/ information-held-federal-court-native-title-files>; see also Chapter 9, this volume. 
In 2011, the NAA endorsed the Federal Court's records authority, which sets out the framework for the management and disposal of its case file records. ${ }^{73}$ The authority delineates the requirements for 'keeping and destroying records for the core business area of case management', as well as for the purposes of national preservation. The authority states:

in the interests of accountability and consistent decision making and preservation of the archival resources of the Commonwealth, records identified as 'retain as national archives' are to be transferred to the custody of NAA by mutual agreement. ${ }^{74}$

The authority covers all records of the 'core business of deciding disputes according to law', including judges' coram books, papers and all administrative tasks performed in the function of deciding a dispute, as well as judicial committee matters, a master set of judgments and other administrative records. ${ }^{75}$ Importantly, it specifies that 10 per cent of 'significant non-native title Court files' that have been nominated by the judges are to be retained as national archives. The decision to retain a case file is made on the basis of its value as precedent, high media profile, public interest and case diversity, and that it should represent a crosssection of cases within a year.

The separate identification and treatment of native title court files, all of which are to be preserved and transferred to the NAA, recognises the historical and archival value attached to the information contained in these records. As Pamela McGrath discusses in another chapter in this collection, as a result of native title legal proceedings, the Federal Court is in possession of an enormous number of records that contain information about thousands of Indigenous people, both living and deceased. The onerous evidentiary requirements imposed by the legislation have resulted in 'one of the most substantial government-sponsored research efforts ever undertaken with Indigenous Australians', including genealogical, cultural and historical information that is often personal or culturally sensitive. ${ }^{76}$ As McGrath argues, providing public access to native title records raises

73 National Archives of Australia, Records Authority: Federal Court of Australia, No 2010/00315821, 19 October 2011.

74 Ibid 4.

75 Also exhibit administration, file inspection arrangements, legal assistance, development of policy and procedures, research, reviewing and reporting, taxation of costs, remitted or transferred matters, judges' meetings, development of court rules and practice notes, and consultation with stakeholders. 76 Chapter 10, this volume. 
significant and intersecting legal and ethical interests that 'complicate the possibility of making native title records publicly available through either archives or publication'. ${ }^{77}$

The Federal Court is also required to comply with a freeze placed by the NAA on disposal of records affecting the rights and entitlements of Indigenous people. This was in response to the recommendations of the Royal Commission into Aboriginal Deaths in Custody ${ }^{78}$ and the Bringing Them Home report into the removal of Aboriginal children from their families and communities. ${ }^{79}$ These recommendations were intended to assist Indigenous people in the process of re-establishing community and family links with those from whom they have been separated under past government policies. ${ }^{80}$ The freeze was extended in 2000 to cover records still in the custody of a range of government agencies; and again, in 2009 , to cover records that contain information on policy and procedures about withholding wages, pensions and allowances from Indigenous Australians. ${ }^{81}$ The Federal Court is included as one of the agencies responsible for retention of these files, which is reflected in its policy to retain all native title case files.

The Federal Court's records authority establishes 10 classes of records related to case management. Four classes deal with case files-that is, files containing material relating to individual proceedings. The default position for every case file is that material constituting the 'court record', as defined by the Federal Court for the purposes of the authority (referred to as 'Part A' of each file), is retained by the court. ${ }^{82}$ This is consistent with the court's status, established under Chapter III of the Constitution, as a 'superior court of record'.$^{83}$ Material that is not part of the court record (referred to as 'Part B') may be disposed of between 10 and 25 years after the end of the

77 Ibid.

78 Commonwealth, Royal Commission into Aboriginal Deaths in Custody, National Report, Overview and Recommendations (1991), Recommendation 53.

79 Above n 15, Recommendation 21.

80 National Archives of Australia, Records Disposal Freezes and Retention Notices (25 January 2018) National Archives of Australia.<www.naa.gov.au/information-management/managing-informationand records/disposal/freezes/index.aspx\#section9>.

81 Ibid.

82 In this category, the authority specifically identifies categories of records: cross-claims and replies; fast-track statements and responses; pleadings; requests for particulars and particulars in response; where the proceeding is an appeal, the notices; where the proceeding is commenced by way of petition, the petition and any answering document; court documents that identify the parties; court documents that record the final orders; reasons for judgment (where published) and copies of orders. 83 Federal Court of Australia Act 1976 (Cth) s 5. 
proceedings ${ }^{84}$ However, certain classes of case files have been identified as so important that their entire contents (both Parts A and B) are to be permanently retained by the NAA as a national archive. These are specified as all native title case files and significant, non-native title files.

The RDA gives the court responsibility for deciding which cases are 'significant', subject to the condition that the number of cases selected not exceed 10 per cent of all cases finalised by the court in any one year. However, there is less specificity about the rationale for identification of what constitutes a 'significant' case, and the process and selection criteria are still to be finalised. During consultation with the court as part of the research for the Court as Archive Project, two general criteria for determining a significant case have been suggested: first, precedential cases, being cases likely to set a new precedent or change an existing precedent; and second, cases likely to have a long-term historical interest due to the parties involved in the dispute or issues involved in the case. Further, the authority specifies that factors for consideration in identifying significant cases should include 'high media profile', 'public interest' and a 'crosssection of cases'.

Preserving cases 'likely to be of long-term historical interest' is a wide and open-ended criterion that begs for clarification. Further, the factors that may be considered in determining the criteria are likely to change, reflecting the social and political problems of a particular time. This should be appropriately reflected in the nature of the cases selected for preservation. As researchers on the Court as Archive Project, rather than identify a definitive list of additional factors (which would require review over the longer term), we have recommended that attention should be directed to the process by which the criteria and factors are applied. This process involves the establishment of a committee to oversee the identification of significant cases, with membership drawn from the court's judges, senior executive and key committees. In addition, we recommend that the committee include experts in Australian history, public law, and

84 This includes applications for fee waiver or exemption, applications to inspect files, letters to and from parties, minutes of orders for directions, consent orders and final orders, as well as exhibits that have not been returned to parties, list of exhibits, submissions, legal arguments or interpretation of evidence and transcripts of proceedings. Other records included in Part B and subject to disposal include audio recordings of court transcripts (apart from native title matters), which are to be destroyed 10 years after the date recorded; records documenting the court's docket system, which may be destroyed five years after completion; and records documenting the routine operational administrative tasks of the core business of the court, which may be destroyed seven years after completion. 
archives and library special collections. The recommendation, in the form of a memo delivered to Chief Executive Officer Warwick Soden, is included in this collection. ${ }^{85}$

\section{Conclusion}

Tom Nesmith argues that it is not only decisions about what records to retain as archival but also what is not preserved, what is disposed of through the process of sentencing, that contributes to meaning-making processes based on archival practices. ${ }^{86}$ In this chapter, I have investigated the role of courts as archives through an analysis of approaches to appraisal of court records. I have argued that courts must carefully consider their records disposal policies and practices because they are ultimately responsible for the decisions to retain or destroy records. The decision to keep or destroy records can have a significant impact not only on the parties directly involved in the legal process, but also on how law is understood historically and contemporaneously. In Canada and Australia, courts of record, including the Supreme Court of Canada, Federal Court of Canada and Federal Court of Australia, have begun to grapple with these obligations by developing frameworks for archival appraisal through records RDAs. This has raised important questions about their legal and ethical responsibilities in relation to court records and led to consideration of what principles should guide and determine appraisal decisions. It has led them to confront a question that goes to the heart of their identity, and, ultimately defines their record-keeping responsibilities: 'What is a court record?'. I have argued that when considering this question, courts should go beyond legal principles and obligations to consider their archival responsibilities in terms of the deeper public law issues underlying their institutional role. 
This text is taken from The Court as Archive, edited by Ann Genovese, Trish Luker and Kim Rubenstein, published 2019 by ANU Press, The Australian National University, Canberra, Australia. doi.org/10.22459/CA.2019.11 